\title{
An Overview on the Therapeutic Function of Foods Enriched with Plant Sterols in Diabetes Management
}

\author{
Selvaraj Jayaraman ${ }^{1, *},+\mathbb{D}$, Anitha Roy ${ }^{2}$, Srinivasan Vengadassalapathy ${ }^{3}$, Ramya Sekar ${ }^{4}$, \\ Vishnu Priya Veeraraghavan ${ }^{1}$, Ponnulakshmi Rajagopal ${ }^{5}$, Gayathri Rengasamy ${ }^{1}$, Raktim Mukherjee ${ }^{6}$, \\ Durairaj Sekar ${ }^{7, *,+}$ and Reji Manjunathan ${ }^{8, *, \dagger}$
}

Citation: Jayaraman, S.; Roy, A.; Vengadassalapathy, S.; Sekar, R.; Veeraraghavan, V.P.; Rajagopal, P.; Rengasamy, G.; Mukherjee, R.; Sekar, D.; Manjunathan, R. An Overview on the Therapeutic Function of Foods Enriched with Plant Sterols in Diabetes Management. Antioxidants 2021, 10, 1903. https://doi.org/ 10.3390/antiox10121903

Academic Editors: Vanessa Routh and Xavier Fioramonti

Received: 13 October 2021

Accepted: 24 November 2021

Published: 27 November 2021

Publisher's Note: MDPI stays neutral with regard to jurisdictional claims in published maps and institutional affiliations.

Copyright: (C) 2021 by the authors Licensee MDPI, Basel, Switzerland. This article is an open access article distributed under the terms and conditions of the Creative Commons Attribution (CC BY) license (https:// creativecommons.org/licenses/by/ $4.0 /)$.
1 Department of Biochemistry, Saveetha Dental College \& Hospitals, Saveetha Institute of Medical \& Technical Sciences, Chennai 600077, India; vishnupriya@saveetha.com (V.P.V.); gayathri.sdc@saveetha.com (G.R.)

2 Department of Pharmacology, Saveetha Dental College \& Hospitals, Saveetha Institute of Medical \& Technical Sciences, Chennai 600077, India; anitharoy@saveetha.com

3 Department of Pharmacology, Saveetha Medical College and Hospital, Saveetha Institute of Medical \& Technical Sciences, Chennai 602105, India; srinivasanv.smc@saveetha.com

4 Department of Oral Pathology, Meenakshi Ammal Dental College and Hospitals, Chennai 600095, India; drramya.oralpathology@madch.edu.in

5 Department of Central Research Laboratory, Meenakshi Ammal Dental College and Hospitals, Chennai 600095, India; ramgslaks@gmail.com

6 Shree PM Patel Institute of PG Studies and Research in Science, Sardar Patel University, Anand 388001, India; raktimmukherjee2003@gmail.com

7 Centre for Cellular and Molecular Research, Saveetha Dental College and Hospitals, Saveetha Institute of Medical \& Technical Sciences (SIMATS), Saveetha University, Chennai 600077, India

8 Multi-Disciplinary Research Unit, Chengalpattu Government Medical College, Chengalpattu 60300, India

* Correspondence: selvarajj.sdc@saveetha.com (S.J.); durairajsekar.sdc@saveetha.com (D.S.); rejimanjunath@gmail.com (R.M.)

+ These authors contributed equally to this work.

Abstract: Diabetes is one of the most significant health issues across the world. People identified with diabetes are more vulnerable to various infections and are at a greater risk of developing cardiovascular diseases. The plant-based food we consume often contains many sterol-based bioactive compounds. It is well documented that these compounds could effectively manage the processes of insulin metabolism and cholesterol regulation. Insulin resistance followed by hyperglycemia often results in oxidative stress level enhancement and increased reactive oxygen species production. At the molecular level, these changes induce apoptosis in pancreatic cells and hence lead to insulin insufficiency. Studies have proved that plant sterols can lower inflammatory and oxidative stress damage connected with DNA repair mechanisms. The effective forms of phyto compounds are polyphenols, terpenoids, and thiols abundant in vegetables, fruits, nuts, and seeds. The available conventional drug-based therapies for the prevention and management of diabetes are time-consuming, costly, and with life-threatening side effects. Thereby, the therapeutic management of diabetes with plant sterols available in our daily diet is highly welcome as there are no side effects. This review intends to offer an overview of the present scenario of the anti-diabetic compounds from food ingredients towards the therapeutic beneficial against diabetes.

Keywords: diabetes; insulin resistance; plant sterols; enriched foods; epigenetics; inflammation; therapeutic implications

\section{Introduction}

Diabetes mellitus (DM), commonly known as diabetes, is an endocrine disorder characterized by elevated glucose levels [1]. The pancreatic cells produce a metabolic peptide hormone called insulin which allows the entry of glucose from the blood to the cells to support them with energy. A lack of adequate insulin functional balance plays a vital 
role in diabetes development [2]. Diabetes is a chronic disease, and its global prevalence is estimated to be $4.4 \%$ in 2030. According to the International Diabetes Federation (IDF) data, it is estimated that by the year 2045, about 693 million people will be affected by diabetes worldwide, and the most badly hit countries will be the USA, China, and India [3]. Diet plays a significant role in the etiology of many diseases such as diabetes, cancer, and cardiovascular illness, even at a younger age. A healthy diet pattern (less salt, sugars, saturated, and industrial trans-fat but with more green and leafy vegetables and fruits) is essential to maintain good health and to prevent many diseases. Having the habit of following an unhealthy and uncontrolled diet is considered one of the fundamental reasons behind the induction of obesity and overweight [4]. The overweight and obese conditions can lead to many unhealthy situations such as cardiovascular diseases, muscularskeletal disorders, and certain cancers associated with breast, ovarian, colon, and liver. At present, the epidemic death proportion due to obesity-related diseases has reached at least 2.8 million deaths per year globally [5].

Abnormal accumulation of fats results in insulin resistance, impaired glucose tolerance, and even diabetes [6]. In obese conditions, the level of major inflammatory proteins such as interleukin-6 (IL-6) and tumor necrosis factor (TNF- $\alpha$ ) increases significantly. Elevated levels of these inflammatory markers induce dyslipidemia by inviting macrophages towards the adipose tissue [6,7]. Various conditions such as programmed cell death in pancreatic $\beta$ cells due to insulin resistance, hyperglycemia-induced oxidative stress, and enhanced production of reactive oxygen species can lead to diabetes. The phytosterols are natural compounds that include sterol and stanol esters and are abundantly occur in plants' cell membranes. The plant sterols that are commonly present in daily food intake are the $\beta$-sitosterol, campesterol, and stigmasterol. Due to the structural similarity with the body's cholesterol, the phytosterols compete with the cholesterol and help in reducing the absorption of dietary cholesterol [8]. The European Foods Safety Authority (EFSA) declared that the daily consumption of plant sterols within the therapeutic dose (1.5-2.4 g/day) is adequate for disease prevention in humans without harmful side effects [9].

\section{Diabetes}

The Egyptian manuscript mentioned the diabetic condition as "too great emptying of urine", dating back to 1500 BC. The great ancient Indian physician, Sushruta, and the surgeon Charaka identified two types of diabetic conditions at $400 \mathrm{AD}$, later named Type 1 and 2 diabetes [10]. The term "diabetes" was first introduced by Araetus of Cappodocia in 81-133 AD. Later, the word mellitus was coined by Thomas Willis in 1675 after finding the sweetness in the urine and blood of infected patients. Diabetes is a Greek word meaning "to syphon", which indicates rapid drainage of fluid, and the word "mellitus" is a Latin word meaning honey [11]. The diabetic condition is classified into Type 1 and Type 2 diabetes, based on their etiology. Type 1 Mellitus is a chronic autoimmune condition in which the $\beta$ cells of the pancreas stop the production of insulin because of autoimmune disorders and is more prevalent in adolescence. Patients with Type 1 diabetes appear thin to normal by body mass but are identified with ketoacidosis and absolute insulin deficiency. Administration of insulin is the treatment of choice for Type 1 diabetic patients [10].

On the other hand, the prevalence of Type 2 diabetes is more common than Type 1. People who are overweight or obese, 45 years or older, have a family history of diabetes, have pre-diabetic conditions, and are less physically active are more prone to be affected with Type 2 diabetes. Recent trends show that Type 2 diabetes is more common among young adults due to sedimentary lifestyles. Resistance to insulin results in elevated blood glucose levels and induces more insulin production by the pancreas. The work burden damages the $\beta$-cells of the pancreas and slowly stops the production of insulin. If unnoticed, the condition may badly affect the function of many organs such as the heart, nerves, blood vessels, eyes, and kidneys. There is no permanent cure for diabetes, but it can manage with medication and a healthy lifestyle [12]. 


\subsection{Epidemics and Thrifty Genes}

Diabetes is a global epidemic and will be the seventh leading cause of death by 2030 . The island of Nauru, located in the Pacific Ocean, has the highest prevalence of type 2 diabetes globally, with more than $40 \%$ of people affected [13]. In the early 20th century, the Nauru people suffered from starvation due to lacking basic nutrition sustenance. In 1922, they discovered phosphate rocks in their land and were given royalties for the same. This incident made them rich, and people started leading an unhealthy sedentary lifestyle. They stopped agriculture and fishery farms, which resulted in the explosion of Type 2 diabetes. An American geneticist, Dr. James V. Neel, first proposed the "thrifty gene" concept. The theory explains that particular gene variants evolved to favor efficient use of nutrients in a calorie-limited environment may promote obesity and Type 2 diabetes under a modern calorie-rich environment. The thrifty genes potentially enable the collection and processing of food to deposit as fat during abundance to cope with periods of famine. In the case of the Nauruans, the thrifty genes might have been involved in the development of obesity and resulted in the massive epidemic outbreak of Type 2 diabetes [14].

\subsection{Blood Glucose Regulation}

Glucose, the body's primary energy source, can be used as fuel immediately or can be preserved in the form of glycogen in the liver and muscles. The blood glucose level increases steeply after a meal, and the enzymes insulin and glucagon regulate the elevated glucose level. The other hormones, such as somatostatin and amylin, also regulate glucose levels. Insulin is released when there is a surge of glucose in the blood to favor glucose absorption by somatic cells. Insulin also initiates glucose breakdown and helps in extra glucose storage in the liver as glycogen. Cells require insulin to support with protein synthesis process. Insulin can activate the components of the translational machinery, including elFs (eukaryotic initiation factors) and eEFs (eukaryotic elongation factors). In the long term, insulin increases the cellular content of ribosomes to augment the capacity for protein synthesis [15]. While the hormone glucagon performs the way opposite of insulin action (Figure 1).

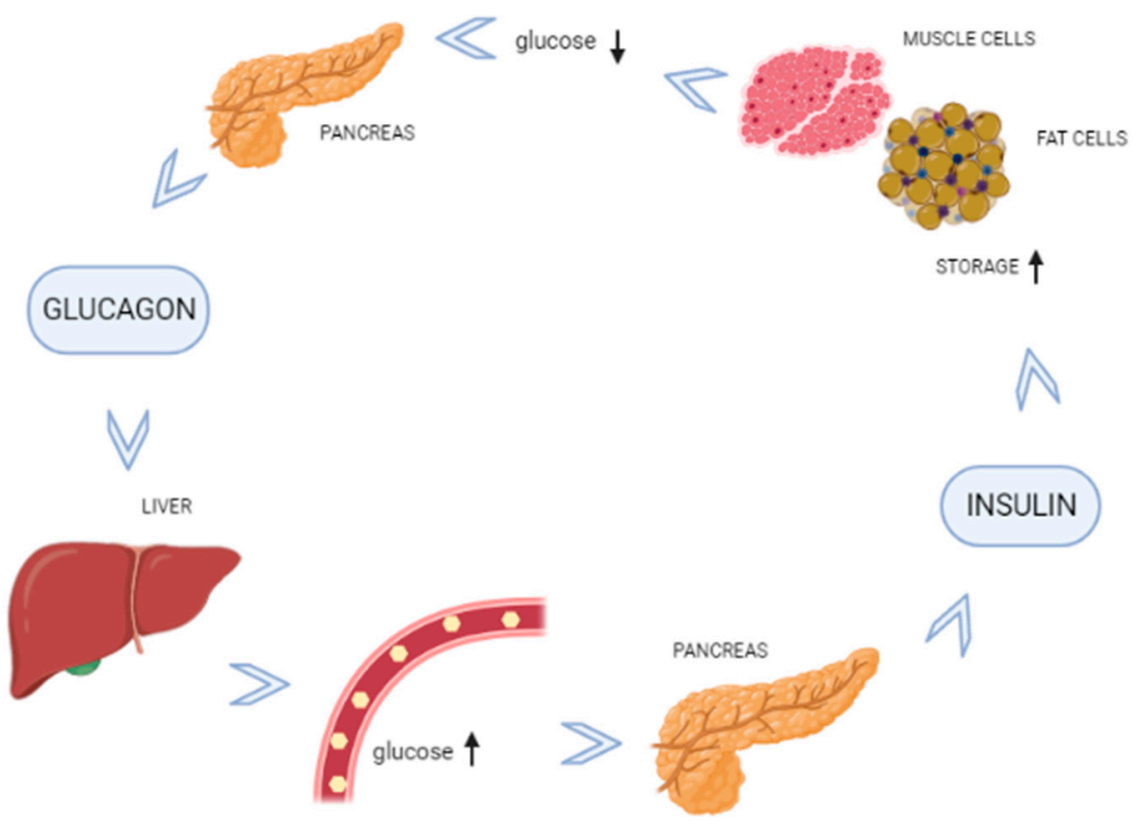

Figure 1. Physiology in the homeostasis of blood glucose level.

\section{Phytosterols}

Phytosterols (PS) are plant-based sterols and stanols having a similar structure to cholesterol. They serve as a structural part of the plant's biological membrane and are 
abundantly present in all plant-based food that we consume daily [16]. PS provides taste and aroma and chemically acts as an anti-oxidant, stabilizer, and modest radical scavenger. The most commonly available plant sterols are $\beta$-sitosterol, campesterol, and stigmasterol. They are majorly known for their hypocholesterolemic, immunomodulation, anti-diabetic, and anti-inflammatory potentials and play an essential role in DNA repair mechanisms [17].

Three significant forms of PS that are well explored up-to-date are:

- Polyphenols include flavonoids, phenolic acids, tannins, and stilbenes.

- Terpenoids include carotenoids and non-carotenoids.

- Thiols includes glucosinolates and indoles (Table 1).

Table 1. Represents the list of plant-derived foods, their scientific names, and the volume of their phytosterols.

\begin{tabular}{|c|c|c|c|}
\hline Plant-Derived Foods & Scientific Names & $\begin{array}{c}\text { Total PS } \\
\text { (mg/100 g) }\end{array}$ & Reference \\
\hline Zucchini & Cucurbita pepo L. & 0.63 & [18] \\
\hline Eggplant & Solanum melongena L. & 0.5 & {$[18]$} \\
\hline Broccoli & Brassica oleracea var. Italica & $4-50$ & {$[18]$} \\
\hline Carrot & Daucus carota $\mathrm{L}$. & $16-30$ & [18] \\
\hline Cauliflower & Brassica oleracea var. Botrytis L. & 44 & {$[18]$} \\
\hline Endive & Cichorium endivia $\mathrm{L}$. & $16-20$ & [19] \\
\hline Spinach & Tetragonia expansa & 16 & {$[19]$} \\
\hline White cabbage & Brassica oleracea var. Capital & 27.4 & [19] \\
\hline Tomato & Lycopersicum esculentum Mill. & $9-10$ & {$[19]$} \\
\hline Green bean & Phaseolus vulgaris & $10-12$ & {$[19]$} \\
\hline Brown rice & Oryza sativa & $18-20$ & [19] \\
\hline Polished rice & Oryza sativa & 9-10 & [19] \\
\hline Green pea & Pisum sativum & 25 & {$[19]$} \\
\hline Brown beans & Phaseolus vulgaris L. & 16 & {$[20]$} \\
\hline Black beans & Phaseolus vulgaris L. & 15 & {$[20]$} \\
\hline Chickpeas & Cicer arietinum & 120 & {$[20]$} \\
\hline Lentil & Lens esculenta & 117 & {$[20]$} \\
\hline Soybean & Glycine max L. Merr. & $32-35$ & {$[20]$} \\
\hline Black soybean & Glycine max L. Merr. & $17-18$ & {$[21]$} \\
\hline Linseed & Linum usitatissimum & $44-45$ & {$[21]$} \\
\hline Acai & Euterpe oleracea & 14 & [21] \\
\hline Avocado & Persea americana & 75 & {$[21]$} \\
\hline Pineapple & Ananas comosus L. Merril & $3-5$ & {$[21]$} \\
\hline Banana & Musa acuminata $\times$ Musa balbisiana & $12-16$ & {$[21]$} \\
\hline Coconut & Cocos nucifera & 14 & {$[22]$} \\
\hline Guava & Psidium guajava L. & $3-5$ & {$[22]$} \\
\hline Orange & Citrus sinensis & $23-24$ & {$[22]$} \\
\hline Apple & Malus Domestica & $13-18$ & {$[22]$} \\
\hline Papaya & Carica papaya & $4-5$ & {$[22]$} \\
\hline Mango & Mangifera indica L. & $1-2$ & {$[22]$} \\
\hline Strawberry & Fragaria vesca L. & $10-15$ & [22] \\
\hline
\end{tabular}


Table 1. Cont.

\begin{tabular}{|c|c|c|c|}
\hline Plant-Derived Foods & Scientific Names & $\begin{array}{c}\text { Total PS } \\
(\mathrm{mg} / 100 \mathrm{~g})\end{array}$ & Reference \\
\hline Canola (Rapeseed) & Brassica napus & $250-878$ & [22] \\
\hline Coconut & Cocos nucifera & $73-75$ & [22] \\
\hline Sunflower & Helianthus annuus & $400-500$ & [22] \\
\hline Corn & Zea mays & $686-1400$ & [22] \\
\hline Soybean & Glycine max & $203-328$ & [22] \\
\hline Olive & Olea europaea & $114-162$ & [22] \\
\hline
\end{tabular}

\subsection{Phytosterols Chemical Structure and Bioavailability}

Phytosterols have a characteristic structure. They have 17 carbon atoms arranged as four tetracyclic cyclopenta- $\alpha$-phenanthrene rings with a C-24 atom side chain. Though they have structural similarity with cholesterol, they vary by a side chain of methyl or ethyl groups (Figure 2) [23]. Because of their lipid modulation properties, plant sterols have recently gained much attention $[24,25]$. Humans are naturally supplemented with plant sterols through the daily diet enriched with vegetables, fruits, wheat germ, whole grains, and many vegetable oils [26]. Plant sterols are present in two forms: free form (free sterols, FSs) and conjugated form [27]. Conjugated forms include: (1) steryl esters (SEs) — formed by coupling with higher fatty acids; (2) steryl glycosides (SGs) — formed by connecting with carbohydrates; and (3) acyl steryl glycosides (ASGs) - an acylated form of steryl glycosides. Suppose the PS consists of a methyl group at the 24th position; it forms a campesterol or can become a $\beta$-Sitosterol or stigmasterol if the position is replaced with an ethyl group. These components are present in the biomembranes of plants and play a vital role in structural stability, regulatory function, and signal transduction.

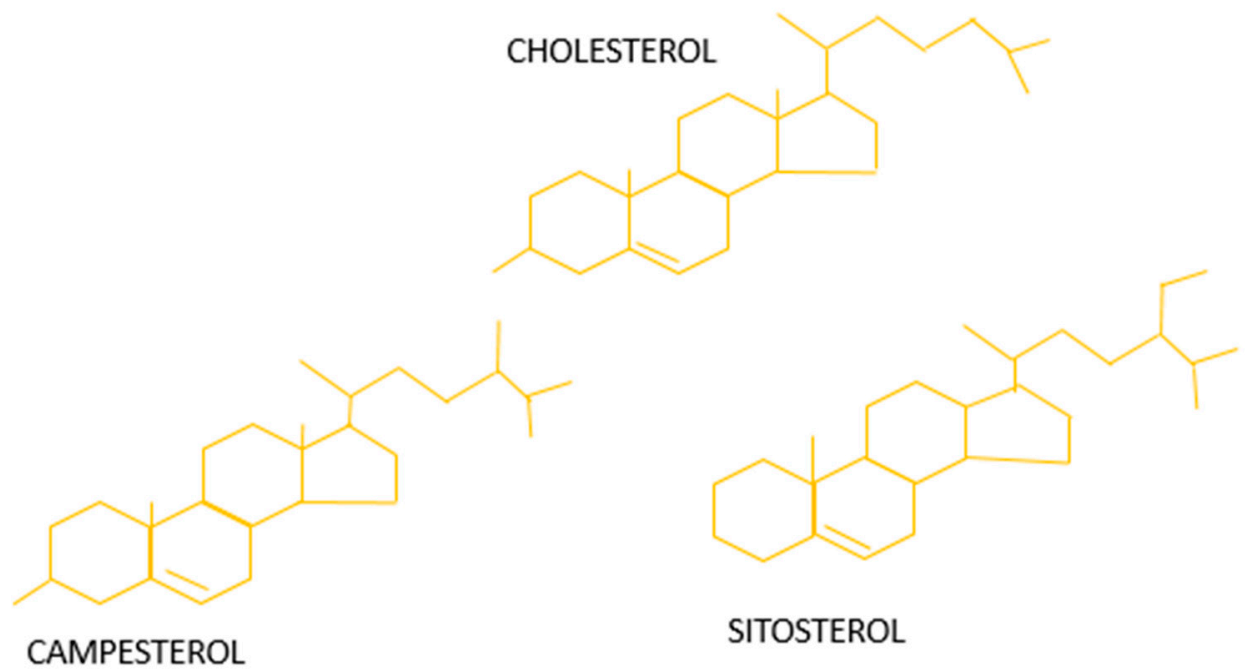

Figure 2. Structure of phytosterols.

Compared to cholesterol, plant sterols are generally less permeable. Plant sterols are solubilized in bile salts and form micelles similar to cholesterol during absorption [28]. The absorption rate of plant sterols is about $5 \%$, but it is 40 to $60 \%$ for cholesterol. The differential plant sterols exhibit different absorption rates, depending on the sterol nucleus and the side chain. The concentration level of sterols in plasma decreases from 0.1 to $0.14 \%$ based on the absorption rate [29]. Dietary supplementation of sterols reduces cholesterol absorption, lowers plasma LDL cholesterol levels, and functions as potent anti-oxidants. The plant sterols could modulate the immune response, oxidative stress, gut dysbiosis, 
mitochondrial dysfunction, and dyslipidemia. Studies have also reported that the sterols and stanols significantly regulate LDL-C serum levels [30]. Many in vitro examinations have been conducted to improve the bioavailability of plant sterols. The mutations that are identified in genes such as ABCG5, ABCG8, NPC1L1, and apolipoprotein E might result in the altered bioavailability of plant sterols [31]. Plant sterols are used therapeutically to lower the cholesterol level and in the formulations of many vitamins [32].

\subsection{Mechanism of Action}

Sterol formation is a multistage process and takes place in the endoplasmic reticulum. Initially, the acetate is converted into the squalene through C5-isoprene via the mevalonate pathway. Secondly, the cyclization of squalene happens and results in the formation of cycloartenol. The cycloartenol converts into the campesterol, $\beta$-sitosterol, stigmasterol, or brassicasterol based on ethyl or methyl groups addition [33] (Figure 3).

The bioavailability of these sterols has been studied by many researchers using both animal and human models [34]. Studies show that the body can absorb only about $5 \%$ of the plant sterols. In infants and young adults, the absorption rate seems to be higher than in adults [35]. Early studies reported that the absorption pattern of PS was a passive diffusion process. Later, it was shown that the sterols competitively solubilize in mixed micelles and cholesterol in the intestine [36]. A complex metabolic process occurs when the PS are taken up with the dietary cholesterol. These complex molecules are reduced into free sterols by the esterases and are taken by micelles. Micelles are the complex of bile salts, phospholipids, free sterols, and fatty acids. In comparison to cholesterol, plant sterols are more favorably solubilized in the intestinal lumen than cholesterol. The mixed micelles are taken up by enterocytes mediated by NPC1L1 at the brush border membrane. This absorbed cholesterol is esterified by fatty acids (ACAT-2) and incorporated into chylomicrons. The formed chylomicrons are first transported into the lymphatic vessel that penetrates each villus called the central lacteal. The chylomicron-rich lymph then drains into the lymphatic system and rapidly flows into blood. The blood-borne chylomicrons are rapidly disassembled, and their constituent lipids are utilized throughout the body. During the metabolic process of esterified cholesterol, the lipoprotein lipase acts upon the chylomicrons at the capillary bed and delivers triglycerides and fat-soluble vitamins to the tissues. The sterols in chylomicrons are primarily taken up by the liver and then cleared eventually. Excess un-esterified cholesterol is shuttle back to the intestine [37-41] Numerous genes such as ATP binding cassette transporter (ABCG5/8) are involved in the secretion of un-esterified cholesterol. The plant sterol's hypocholesterolemic effect depends on the induction of LXR and is regulated by NPC1L1 and ABC transporters [42-46]. However, the exact mechanism behind plant sterol's absorption and transportation is still controversial. Due to the variation in ABCG5 or ABCG8, every individual shows a differential absorption pattern of PS [47]. Animal studies conducted by various researchers show that the plant sterols are highly distributed in the liver, adrenal cortex, ovary, and testis [46,48]. The half-life period of PS is 37, 17, and $15 \mathrm{~min}$ for campesterol, sitosterol, and stigmasterol, respectively. The plant sterols are usually not retained in the body, and most of them are excreted through bile in the feces [49]. The excretion of PS directly facilitates cholesterol excretion from the body and thereby aid in the maintenance of the hypocholesterolemic effect [47]. 


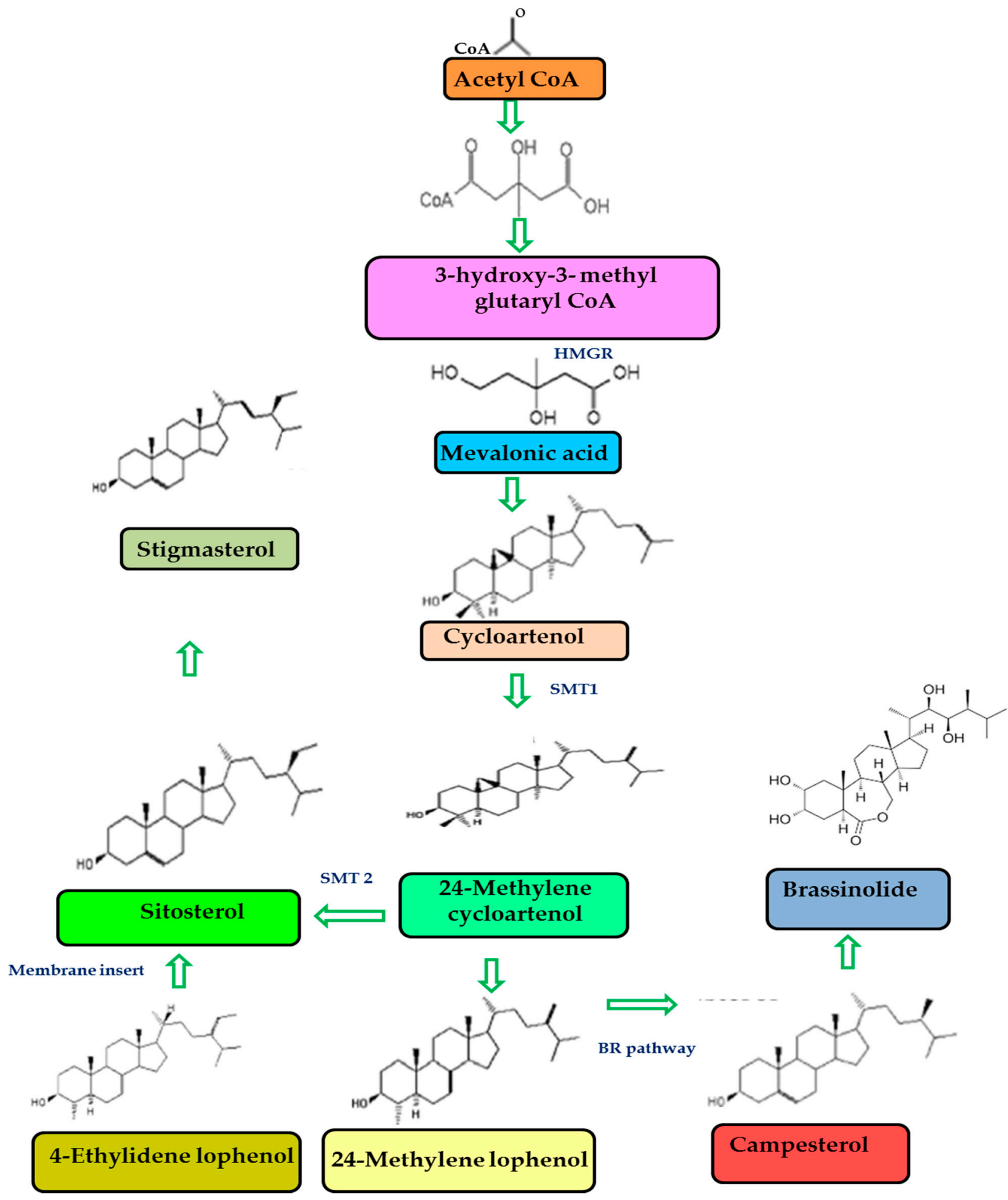

Figure 3. Schematic representation of biosynthetic pathway activated by the major plant sterols: HMGR-3-hydroxy, 3-methylglutaryl coenzyme A reductase; SMT-sterol 24-C-methyltransferase; BR-brassinosteroids.

\section{Diabetes and Cholesterol}

Diabetes Mellitus, a standard, rapidly developing metabolic disorder affecting all age groups, are in serious need of medical attention [50]. By 2035, about 592 million people were expected to be affected by this disorder globally [51]. Diabetes is commonly associated with obesity, resulting in cardiovascular diseases such as ischemic heart disease and stroke [52]. Dyslipidemia is one of the most common features associated with obesity. 
It is also associated with Type 2 diabetes and is marked by increased triglycerides and lowered high-density lipoprotein levels. Type 1 diabetes is also observed with elevated triglycerides but with normal high-density lipoprotein levels. It has been observed that all the lipoprotein levels are found altered in diabetes due to hyperglycemia or insulin resistance [53]. Abnormal lipid profile is a strong indicator for coronary heart disease in Type 1 and 2 diabetic conditions. Although triglycerides do not participate directly in atherosclerotic plaque formation, they play a central role in constructing low-density lipids and impaired HDL cholesterol levels in diabetes conditions [54]. These changes, along with unaltered apoB and cholesterol levels in diabetes, lead to atherogenesis. Pieces of evidence show that therapies used in lowering cholesterol reduce the mortality rate due to cardiovascular diseases with or without diabetes.

\subsection{Genetic and Epigenetic Modulations in Diabetes}

Genetics plays a vital role in the development of Type 2 diabetes than Type 1 . The same also has a more critical link to family history and lineage compared to Type I. Any mutations in proteins such as TCF7L2, ABCC8, GLUT2, and CAPN10 favor the progression of Type 2 diabetes because they could influence the production or mechanism of action of insulin (6). The other genes strongly linked with diabetes are class II MHC, HLA-DQ, HLA-DR, and HLA-DP proteins. Loss of insulin sensitivity in tissues, such as fat, muscle, and liver, is the cause of Type 2 diabetes development [7].

Moreover, Type 2 diabetes can be heritable and associated with obesity rather than its disease [55]. Thereby obesity forms the leading platform in the incidence and progression of DM. Many genes involved in this metabolic process are identified through genome-wide association studies (GWAS), candidate gene studies, and linkage studies. The significant genes associated with T2DM include CAPN10 belonging to the calpain family, involve intracellular remodeling and signaling activities [56,57]. The TCF7L2 gene is the most consistently applied in T2DM induction and produces a transcription factor that affects the Wnt signaling pathway. Many experiments have proven that the increased secretion of TCF7L2 results in the lowering of insulin secretion. Another gene named Peroxisome Proliferator-activated Receptor-gamma Gene (PPARG) is involved in T2DM and contributes to the $20 \%$ risk incidence when arginine replaces the proline at location 12 . Both IRS1 and IRS2 polymorphism interfere with insulin signaling pathways and reduce insulin sensitivity [58]. Missense polymorphism in KCNJ11 alters insulin secretion. SLC30A8 has shown to be widely involved in Type 1 diabetes progression preliminary, and its consistent overexpression ends with the incidence of Type 2 diabetes. Since diabetes is often associated with obesity, the genes related to obesity, such as FTO and MC4R, are often connected with diabetes. Any changes in Pdx1 and Glut4 genes' functions predominantly play a vital role in developing Type 1 diabetes [59]. Epigenetic alterations such as histone methylation, acetylation, phosphorylation, DNA methylation, chromatin remodeling, and oxidative stress play an essential role in promoting and progressing diabetic mellitus. It has been proved that the diet has a predominant control over the epigenetic factors that affect the progression of diabetes. In addition, a baby's gestational age can influence the incidence of obesity and diabetes together [60].

\subsection{Plant Sterols and Anti-Cholesterol Activity}

The human body requires the waxy substance cholesterol to build healthy cells and synthesize hormones and digestive fluids. Overall, cholesterol within the required range helps our body to function correctly. An imbalance between the two forms of cholesterol, such as low and high lipoproteins, increases the chances of developing heart disease and stroke. The hypocholesterolemic effect of plant sterols was identified in early 1950 [61]. Still, many studies are in line to identify the molecular mechanism behind the anti-cholesterol effect of PS. So far, many studies emphasize that the plant sterol could regulate the levels of lipid variables such as LDL, HDL, triglycerides, and apolipoprotein B effectively [62]., Many studies have supported the lipid regulatory action of plant sterols; however, a lack 
of understanding of the mechanism prevents them from being used in clinical trials. Many reports have suggested that the plant sterols and stanols could reduce LDL levels and exert their action in a dose-dependent way $[63,64]$. Some data also show that the stanols could exert a dose-dependent hypocholesterolemic effect compared to sterols [65]. The efficiency of plant sterol may largely depend on the baseline levels of plasma lipids. Studies have shown that plant sterols could effectively lower the concentration of triacylglycerols and thereby reduce the synthesis of very-low-density lipoproteins. Conversely, a few detailed research studies have highlighted the negative association of phyto compounds with hypercholesterolemia impact $[66,67]$.

\subsection{Plant Sterols and Anti-Diabetic Effects}

Plant-based medicines are commonly used to prevent many chronic diseases. They have been in use as a complementary or alternative therapy form since ancient times. For example, the anti-diabetic drug metformin, a derivative from the plant Galega officinalis, is widely used to prevent diabetes $[68,69]$. The other medicinal plants with anti-diabetic properties include Aloe vera, Jamun/Indian blackberry, gurmar, bitter guard, basil, yacon, fenugreek, etc. The various parts of the plants, such as leaves, seeds, roots, and fruits are used to treat diabetes [70-75]. These medicinal plants regulate many functions such as insulin secretion, insulin resistance, glucose absorption, and regulation (Table 2).

Results from animal studies have supported the potent hypoglycemic and hypocholesterolemic effects of plant sterols [76-79]. However, so far, no clinical research has been conducted to verify the impact of plant products as conventional drugs for diabetic management. The plant sterols could regulate the expression of genes such as glucose-6phosphatase, phosphoenolpyruvate carboxykinase, and peroxisome proliferator-activated receptor-alpha and influence the rate of metabolism [80]. Misawa et al. reported that the ethanolic extract of Aloe vera could increase the production of insulin in Zucker diabetic fatty rats [81]. Research by Patil et al. proved the insulin-secreting efficiency of plant sterols present in cumin oil, cumin aldehyde, and cuminol with the help of the diabetic rat model [82]. The research identified that the plant sterol present in black cumin (N. sativa) blocks the sodium-dependent passage of glucose across the jejunum. Long-term treatment of $N$. sativa modulates glucose tolerance and body-weight reduction as equivalent to metformin in a rat model [83]. Indian satinwood (Chloroxylon swietenia) shows a significant hypoglycemic effect in streptozotocin-induced diabetic rats [84]. The ethyl acetate extract of fruits of weeping forsythia could effectively enhance the plasma level of insulin [85]. The ethanolic extract of scarlet gourds (Coccinia grandis) leaves exerts its hypoglycemic activity by reducing the plasma glucose level and increasing the serum insulin level [86]. These plant compounds are noticed for their ability to induce hypoglycemic impact via improving the mechanism of insulin secretion.

Research using the common nettle (Urtica dioica) leaves extract identified the genderbiased working modulation of plant sterols. The study proved that the compound could balance hypoglycemic activities in male Wistar rats. It could effectively reduce the plasma glucose level and fasting insulin resistance index in male rats [87]. The extract of cashew tree (Anacardium occidentale) could significantly reduce the blood glucose levels in STZ induced diabetic rats. In this experiment, the compound showed its ability to reduce fasting glucose levels [88]. An oil extracted from garlic (Allium sativum) helps to improve insulin secretion and glucose tolerance. It proved that the extract could enhance glycogenesis by increasing GLUT4 expression in the rat model [89]. The bark extract of the Sapphire berry family (Symplcos cochinchinesis) has been shown to improve insulin resistance and thus reduce glucose levels [90]. Similar results are observed upon the use of the extract of Helicteres angustifolia [91]. Other plant extracts that work by a similar mechanism to reduce the blood glucose level with effective insulin sensitivity modulation include the Pleurotus ostreatus, Afzelia africana, Uvaria chamae, and resveratrol [92-95].

Some phyto compounds act by inhibiting the $\alpha$-glucosidase, thereby preventing carbohydrate metabolism. Reduced carbohydrate metabolism results in a decreased rate of 
glucose assimilation and could lead to a reduced postprandial glucose level in the blood. Many plants such as basil contain phyto compounds that inhibit enzymes such as $\alpha$ - glucosidase and $\alpha$-amylase, thereby acting as a potent anti-hyperglycemic agent [96]. On chromatographic separation, the basil leaves are found to contain flavonoids, glycosides, steroids, and tannins [97]. The polyphenol compounds isolated from the jute plant exert its potential by inhibiting ACE and lowering the levels of $\alpha$ - glucosidase and $\alpha$ - amylase significantly $[98,99]$. Certain legumes like soybean have been shown to contain polyphenolic compounds such as isoflavones [100]. The phyto compounds of fig fruits such as vitexin and isovitexin were shown to have glucose reduction properties in sucrose-loaded mice [101]. The figs (Ficus deltoidea) are considered an alternative natural remedy for diabetes and are also available in many commercial forms. Plant sterols have been shown to improve insulin production, GLUT4 expression, and insulin sensitivity. As well it inhibits $\alpha$ glucosidase, $\alpha$ amylase, and ACE functions. In addition, the plant-derived compounds also regulate genetic and epigenetic factors to counteract diabetes. More clinical research is necessary to support the therapeutic potential of plant sterols in preventing diabetes.

Table 2. Anti-diabetic activity of different herbs.

\begin{tabular}{|c|c|c|c|c|c|}
\hline Botanical Name & Common Name & Components Used & Animal Studies & Effects & Reference \\
\hline Aloe barbadensis & Aloe vera & Leaves & Diabetic rats & $\begin{array}{l}\text { Significant reduction in the } \\
\text { levels of the enzymes that } \\
\text { facilitate carbohydrate } \\
\text { metabolism }\end{array}$ & {$[81]$} \\
\hline Cuminum cyminum & Cumin & seeds & Diabetic rats & Improves insulin secretion & [82] \\
\hline Nigella sativum & Black cumin & Seeds & Rats & Improves glucose tolerance & {$[83]$} \\
\hline $\begin{array}{c}\text { Chloroxylon } \\
\text { switenia }\end{array}$ & Indian satinwood & Barks & Diabetic albino rats & Decreases blood glucose level & {$[84]$} \\
\hline Forsythia suspense & Weeping forsythia & Fruits & $\begin{array}{l}\text { STZ induced } \\
\text { Kunming mice }\end{array}$ & $\begin{array}{l}\text { Significant reduction in blood } \\
\text { glucose level }\end{array}$ & [85] \\
\hline Coccinia grandis & Scarlet gourds & Leaf & Diabetic Wistar rats & $\begin{array}{l}\text { Improves insulin-secretagogue } \\
\text { and cytoprotective activities }\end{array}$ & [86] \\
\hline Afzelia africana & African mahogany & Stem & Diabetic Wistar rats & Reduces hyperglycemia & [93] \\
\hline Urtica dioica & Common nettle & Leaf & $\begin{array}{l}\text { Fructose induced Insulin } \\
\text { resistance Wistar rats }\end{array}$ & $\begin{array}{l}\text { Significantly reduces } \\
\text { hyperglycemia and } \\
\text { insulin resistance }\end{array}$ & {$[87]$} \\
\hline $\begin{array}{l}\text { Anacardium } \\
\text { accidentale }\end{array}$ & Cashew tree & Leaf & $\begin{array}{l}\text { Diabetes induced female } \\
\text { albino Wistar rats }\end{array}$ & $\begin{array}{l}\text { Significant reduction in the } \\
\text { levels of serum glucose, } \\
\text { glycosylated haemoglobin, FIRI, } \\
\text { and serum insulin }\end{array}$ & [88] \\
\hline Pleurotus ostreatus & Oyster mushroom & & $\begin{array}{l}\text { Diabetes induced male } \\
\text { Wistar rats }\end{array}$ & $\begin{array}{l}\text { Significant reduction in blood } \\
\text { glucose level }\end{array}$ & {$[92]$} \\
\hline Uvaria chamae & Bush banana & Root & $\begin{array}{l}\text { Diabetes induced } \\
\text { albino rats }\end{array}$ & $\begin{array}{l}\text { Significant improvement in the } \\
\text { regeneration of islets } \\
\text { of Langerhans }\end{array}$ & {$[94]$} \\
\hline $\begin{array}{l}\text { Cinnamomum } \\
\text { zeylanicum }\end{array}$ & Cinnamon & Bark & STZ-induced rats & $\begin{array}{c}\text { Significantly diminishes } \\
\alpha \text {-glucosidase activity }\end{array}$ & [73] \\
\hline Ocimum basilicum & Basil & Leaves & & $\begin{array}{c}\text { Significantly inhibits } \alpha \text { amylase } \\
\text { activity in a } \\
\text { dose-dependent manner }\end{array}$ & [97] \\
\hline Corchorus olitorius & Jute & Leaves & & $\begin{array}{l}\text { Significantly inhibits the } \\
\text { enzymatic activities of } \\
\alpha \text {-amylase, } \alpha \text {-glucosidase, } \\
\text { and ACE }\end{array}$ & [99] \\
\hline Ficus deltoidea & Fig & Leaves, Flowers & STZ-induced diabetic rats & $\begin{array}{l}\text { Significantly lowers the blood } \\
\text { glucose level }\end{array}$ & {$[101]$} \\
\hline $\begin{array}{c}\text { Holarrhena } \\
\text { antidysenterica }\end{array}$ & Bitter oleander & Seeds & $\begin{array}{c}\text { Starch-loaded } \\
\text { normoglycemic rats }\end{array}$ & Interferes with starch digestion & {$[75]$} \\
\hline Olea europaea & Olive & Leaves & STZ-induced diabetic rats & Inhibits $\alpha$ amylase activity & {$[72,74]$} \\
\hline Glycine max & Soybean & Soybean & & $\begin{array}{c}\text { Significantly lowers the levels } \\
\text { of } \alpha \text {-amylase, } \alpha \text {-glucosidase } \\
\text { and ACE }\end{array}$ & {$[100]$} \\
\hline
\end{tabular}




\section{Conclusions}

Phyto compounds, the naturally obtained formulations from plants, are well known for their effective anti-diabetic properties. They can exert their function directly by interacting with several signaling pathways associated with diabetes. They also have a potent hypocholesterolemic effect, which could indirectly counteract those obesity-related issues connected with diabetes. In conclusion, we strongly support that due to fewer side effects with significant medicinal character, plant sterols and stanols can be widely used to prevent diabetes. More clinical trials are needed to reveal the anti-diabetic benefits of plant compounds to commercialize them as therapeutic agents.

Author Contributions: S.J., D.S. and R.M. (Reji Manjunathan) conceptualized the idea and prepared the draft; S.V., V.P.V., A.R. and R.S. reviewed and wrote the manuscript; S.J., R.M. (Raktim Mukherjee) and G.R., revised the manuscript; P.R., did review of literature. All authors have read and agreed to the published version of the manuscript.

Funding: Financial support from the Science and Engineering Research Board (SERB-DST), Government of India (Project file No.: EEQ/2019/000568) is greatly acknowledged.

Acknowledgments: We thank Yuvaraj Sambandam for the manuscript editing.

Conflicts of Interest: The authors declare no conflict of interest.

\section{References}

1. American Diabetes Association: Diagnosis and classification of diabetes mellitus. Diabetes Care 2009, 32, S62-S67. [CrossRef]

2. Röder, P.V.; Wu, B.; Liu, Y.; Han, W. Pancreatic regulation of glucose homeostasis. Exp. Mol. Med. 2016, 48, e219. [CrossRef] [PubMed]

3. Cho, N.H.; Shaw, J.E.; Karuranga, S.; Huang, Y.; da Rocha Fernandes, J.D.; Ohlrogge, A.W.; Malanda, B. IDF Diabetes Atlas: Global estimates of diabetes prevalence for 2017 and projections for 2045. Diabetes Res. Clin. Pract. 2018, 138, 271-281. [CrossRef] [PubMed]

4. Purnell, J.Q. Definitions, Classification, and Epidemiology of Obesity. In Endotext; Feingold, K.R., Anawalt, B., Boyce, A., Chrousos, G., de Herder, W.W., Dhatariya, K., Dungan, K., Hershman, J.M., Hofland, J., Kalra, S., Kaltsas, G., et al., Eds.; MDText.com, Inc.: South Dartmouth, MA, USA, 2018.

5. Ahirwar, R.; Mondal, P.R. Prevalence of obesity in India: A systematic review. Diabetes Metab. Syndr. 2019, 13, 318-321. [CrossRef] [PubMed]

6. Gutierrez, D.A.; Puglisi, M.J.; Hasty, A.H. Impact of increased adipose tissue mass on inflammation: Insulin resistance, and dyslipidemia. Curr. Diabetes Rep. 2009, 9, 26-32. [CrossRef] [PubMed]

7. Leitner, D.R.; Frühbeck, G.; Yumuk, V.; Schindler, K.; Micic, D.; Woodward, E.; Toplak, H. Obesity and Type 2 Diabetes: Two Diseases with a Need for Combined Treatment Strategies-EASO Can Lead the Way. Obes. Facts 2017, 10, 483-492. [CrossRef]

8. Cabral, C.E.; Klein, M. Phytosterols in the Treatment of Hypercholesterolemia and Prevention of Cardiovascular Diseases. Arq. Bras. Cardiol. 2017, 109, 475-482. [CrossRef]

9. Martianto, D.; Bararah, A.; Andarwulan, N.; Średnicka-Tober, D. Cross-Sectional Study of Plant Sterols Intake as a Basis for Designing Appropriate Plant Sterol-Enriched Food in Indonesia. Nutrients 2021, 13, 452. [CrossRef]

10. Tipton, C.M. Susruta of India: An unrecognized contributor to the history of exercise physiology. J. Appl. Physiol. 2008, 104, 1553-1556. [CrossRef]

11. Dean, L.; McEntyre, J. The Genetic Landscape of Diabetes [Internet]; National Center for Biotechnology Information (US): Bethesda, MD, USA, 2004.

12. Wolfsdorf, J.I.; Sperling, M.A. Diabetes Mellitus. In Textbook of Clinical Pediatrics; Elzouki, A.Y., Harfi, H.A., Nazer, H.M., Stapleton, F.B., Oh, W., Whitley, R.J., Eds.; Springer: Berlin/Heidelberg, Germany, 2012.

13. Speakman, J.R. Thrifty genes for obesity: An attractive but flawed idea, and an alternative perspective: The 'drifty gene' hypothesis. Int. J. Obes. 2008, 32, 1611-1617.

14. Neel, J.V. Diabetes mellitus: A “thrifty" genotype rendered detrimental by progress. Am. J. Hum. Genet. 1962, 14, 353-362. [PubMed]

15. Kharroubi, A.T.; Darwish, H.M. Diabetes mellitus: The epidemic of the century. World J. Diabetes. 2015, 6, 850-867. [CrossRef] [PubMed]

16. Saravanan, M.; Ignacimuthu, S. Hypocholesterolemic effect of Indian medicinal plants-A review. Med. Chem. 2015, 5, 40-49. [CrossRef]

17. Shahidi, F.; Ambigaipalan, P. Phenolics and polyphenolics in foods, beverages and spices: Anti-oxidant activity and health effects-A review. J. Funct. Foods 2015, 18, 820-897. [CrossRef] 
18. Yang, R.; Xue, L.; Zhang, L.; Wang, X.; Qi, X.; Jiang, J.; Yu, L.; Wang, X.; Zhang, W.; Zhang, Q.; et al. Phytosterol Contents of Edible Oils and Their Contributions to Estimated Phytosterol Intake in the Chinese Diet. Foods 2019, 8, 334. [CrossRef]

19. Zhang, Y.; Chen, L.; Hu, G.Q.; Zhang, N.; Zhu, X.D.; Yang, K.Y.; Jin, F.; Shi, M.; Chen, Y.P.; Hu, W.H.; et al. Gemcitabine and Cisplatin Induction Chemotherapy in Nasopharyngeal Carcinoma. N. Engl. J. Med. 2019, 381, 1124-1135. [CrossRef]

20. Ostlund, R.E., Jr. Phytosterols in human nutrition. Annu. Rev. Nutr. 2002, 22, 533-549. [CrossRef] [PubMed]

21. Moreau, R.A.; Whitaker, B.D.; Hicks, K.B. Phytosterols, phytostanols, and their conjugates in foods: Structural diversity, quantitative analysis, and health-promoting uses. Prog. Lipid Res. 2002, 41, 457-500. [CrossRef]

22. Martins, C.M.; Fonseca, F.A.; Ballus, C.A.; Figueiredo-Neto, A.M.; Meinhart, A.D.; de Godoy, H.T.; Izar, M.C. Common sources and composition of phytosterols and their estimated intake by the population in the city of São Paulo, Brazil. Nutrition 2013, 29, 865-871. [CrossRef]

23. Nowicka, B.; Kruk, J. Occurrence biosynthesis and function of isoprenoid quinones. Biochim. Biophys. Acta 2010, 1797, 1587-1605. [CrossRef]

24. Griebel, T.; Zeier, J. A role for beta-sitosterol to stigmasterol conversion in plant-pathogen interactions. Plant J. 2010, 63, 254-268. [CrossRef]

25. Sardinia, S.; Manali, A.; Gohari, A.R.; Abdollahi, M. The story of beta-sitosterol-a review. Eur. J. Med. Plants 2014, 4, 590-609.

26. Dufourc, E.J. Sterols and membrane dynamics. J. Chem. Biol. 2008, 1, 63-77. [CrossRef]

27. Ferrer, A.; Altabella, T.; Arró, M.; Boronat, A. Emerging roles for conjugated sterols in plants. Prog. Lipid Res. 2017, 67, 27-37. [CrossRef] [PubMed]

28. Amiot, M.J.; Knol, D.; Cardinault, N.; Nowicki, M.; Bott, R.; Antona, C.; Borel, P.; Bernard, J.P.; Duchateau, G.; Lairon, D. Phytosterol ester processing in the small intestine: Impact on cholesterol availability for absorption and chylomicron cholesterol incorporation in healthy humans. J. Lipid Res. 2011, 52, 1256-1264. [CrossRef] [PubMed]

29. Salehi, B.; Quispe, C.; Sharifi-Rad, J.; Cruz-Martins, N.; Nigam, M.; Mishra, A.P.; Konovalov, D.A.; Orobinskaya, V.; Abu-Reidah, I.M.; Zam, W.; et al. Phytosterols: From Preclinical Evidence to Potential Clinical Applications. Front. Pharmacol. 2021, 11, 599959. [CrossRef]

30. Vezza, T.; Canet, F.; de Marañón, A.M.; Bañuls, C.; Rocha, M.; Víctor, V.M. Phytosterols: Nutritional Health Players in the Management of Obesity and Its Related Disorders. Antioxidants 2020, 9, 1266. [CrossRef]

31. Jones, P.; Shamloo, M.; MacKay, D.S.; Rideout, T.C.; Myrie, S.B.; Plat, J.; Roullet, J.B.; Baer, D.J.; Calkins, K.L.; Davis, H.R.; et al. Progress and perspectives in plant sterol and plant stanol research. Nutr. Rev. 2018, 76, 725-746. [CrossRef] [PubMed]

32. Gylling, H.; Plat, J.; Turley, S.; Ginsberg, H.; Ellegård, L.; Jessup, W.; Jones, P.; Lütjohann, D.; Maerz, W.; Masana, L.; et al. Plant sterols and plant stanols in the management dyslipidaemia and prevention of cardiovascular disease. Atherosclerosis 2013, 232, 346-360. [CrossRef] [PubMed]

33. Dewick, P.M. Medicinal Natural Products: A Biosynthetic Approach, 2nd ed.; Wiley: Chichester, UK; New York, NY, USA, 2002.

34. Kongduang, D.; Wungsintaweekul, J.; de-Eknamkul, W. Biosynthesis of $\beta$-sitosterol and stigmasterol proceeds exclusively via the mevalonate pathway in cell suspension cultures of Croton stellatopilosus. Tetrahedron Lett. 2008, 49, 4067-4072. [CrossRef]

35. Miras-Moreno, B.; Sabater-Jara, A.B.; Pedreño, M.A.; Almagro, L. Bioactivity of Phytosterols and Their Production in Plant in Vitro Cultures. J. Agric. Food Chem. 2016, 64, 7049-7058. [CrossRef]

36. Sonawane, P.D.; Pollier, J.; Panda, S.; Szymanski, J.; Massalha, H.; Yona, M.; Unger, T.; Malitsky, S.; Arendt, P.; Pauwels, L.; et al. Plant cholesterol biosynthetic pathway overlaps with phytosterol metabolism. Nat. Plants 2016, 3, 16205. [CrossRef]

37. Jesch, E.D.; Carr, T.P. Food Ingredients That Inhibit Cholesterol Absorption. Prev. Nutr. Food Sci. 2017, $22,67-80$.

38. Gylling, H.; Simonen, P. Phytosterols, Phytostanols, and Lipoprotein Metabolism. Nutrients 2015, 7, 7965-7977. [CrossRef]

39. Cohn, J.S.; Kamili, A.; Wat, E.; Chung, R.W.; Tandy, S. Reduction in intestinal cholesterol absorption by various food components: Mechanisms and implications. Atheroscler. Suppl. 2010, 11, 45-48. [CrossRef] [PubMed]

40. Nunes, C.; Barreto Arantes, M.; Menezes de Faria Pereira, S.; Leandro da Cruz, L.; de Souza Passos, M.; Pereira de Moraes, L.; Vieira, I.; Barros de Oliveira, D. Plants as Sources of Anti-Inflammatory Agents. Molecules 2020, 25, 3726. [CrossRef]

41. De Jong, A.; Plat, J.; Bast, A.; Godschalk, R.W.; Basu, S.; Mensink, R.P. Effects of plant sterol and stanol ester consumption on lipid metabolism, anti-oxidant status and markers of oxidative stress, endothelial function and low-grade inflammation in patients on current statin treatment. Eur. J. Clin. Nutr. 2008, 62, 263-273. [CrossRef] [PubMed]

42. Dumolt, J.H.; Rideout, T.C. The Lipid-lowering Effects and Associated Mechanisms of Dietary Phytosterol Supplementation. Curr. Pharm. Des. 2017, 23, 5077-5085. [CrossRef]

43. Rideout, T.C.; Marinangeli, C.; Harding, S.V. Triglyceride-Lowering Response to Plant Sterol and Stanol Consumption. J. AOAC Int. 2015, 98, 707-715. [CrossRef] [PubMed]

44. De Smet, E.; Mensink, R.P.; Plat, J. Effects of plant sterols and stanols on intestinal cholesterol metabolism: Suggested mechanisms from past to present. Mol. Nutr. Food Res. 2012, 56, 1058-1072. [CrossRef]

45. Chen, H.C. Molecular mechanisms of sterol absorption. J. Nutr. 2001, 131, 2603-2605. [CrossRef] [PubMed]

46. Brufau, G.; Kuipers, F.; Lin, Y.; Trautwein, E.A.; Groen, A.K. A reappraisal of the mechanism by which plant sterols promote neutral sterol loss in mice. PLoS ONE 2011, 6, e21576. [CrossRef]

47. Patel, S.B. Recent advances in understanding the STSL locus and ABCG5/ABCG8 biology. Curr. Opin. Lipidol. 2014, 25, 169-175. [CrossRef] 
48. Solati, Z.; Moghadasian, M.H. Use of Animal Models in Plant Sterol and Stanol Research. J. AOAC Int. 2015, 98, 691-696. [CrossRef]

49. National Center for Biotechnology Information. PubChem Compound Summary for CID 5280794, Stigmasterol. 2021. Available online: https:// pubchem.ncbi.nlm.nih.gov/compound/Stigmasterol (accessed on 23 November 2021).

50. Tabish, S.A. Is Diabetes Becoming the Biggest Epidemic of the Twenty-first Century? Int. J. Health Sci. 2007, 1, V-VIII.

51. Guariguata, L.; Whiting, D.R.; Hambleton, I.; Beagley, J.; Linnenkamp, U.; Shaw, J.E. Global estimates of diabetes prevalence for 2013 and projections for 2035. Diabetes Res. Clin. Pract. 2014, 103, 137-149. [CrossRef] [PubMed]

52. Chadt, A.; Scherneck, S.; Joost, H.G.; Al-Hasani, H. Molecular links between Obesity and Diabetes: "Diabesity". [Updated 23 January 2018]. In Endotext [Internet]; Feingold, K.R., Anawalt, B., Boyce, A., Chrousos, G., de Herder, W.W., Dhatariya, K., Dungan, K., Hershman, J.M., Hofland, J., Kalra, S., et al., Eds.; MDText.com, Inc.: South Dartmouth, MA, USA, 2000. Available online: https:/ / www.ncbi.nlm.nih.gov/books/NBK279051/ (accessed on 23 November 2021).

53. Schofield, J.D.; Liu, Y.; Rao-Balakrishna, P.; Malik, R.A.; Soran, H. Diabetes Dyslipidemia. Diabetes Ther. Res. Treat. Educ. Diabetes Relat. Disord. 2016, 7, 203-219. [CrossRef]

54. Borén, J.; Chapman, M.J.; Krauss, R.M.; Packard, C.J.; Bentzon, J.F.; Binder, C.J.; Daemen, M.J.; Demer, L.L.; Hegele, R.A.; Nicholls, S.J.; et al. Low-density lipoproteins cause atherosclerotic cardiovascular disease: Pathophysiological, genetic, and therapeutic insights: A consensus statement from the European Atherosclerosis Society Consensus Panel. Eur. Heart J. 2020, 41, $2313-2330$. [CrossRef]

55. Kwak, S.H.; Park, K.S. Recent progress in genetic and epigenetic research on type 2 diabetes. Exp. Mol. Med. 2016, 48, e220. [CrossRef]

56. Gu, H.F. Genetic and Epigenetic Studies in Diabetic Kidney Disease. Front. Genet. 2019, 10, 507. [CrossRef]

57. Stankov, K.; Benc, D.; Draskovic, D. Genetic and epigenetic factors in etiology of diabetes mellitus type 1. Pediatrics 2013, 132, 1112-1122. [CrossRef] [PubMed]

58. De Rosa, S.; Arcidiacono, B.; Chiefari, E.; Brunetti, A.; Indolfi, C.; Foti, D.P. Type 2 Diabetes Mellitus and Cardiovascular Disease: Genetic and Epigenetic Links. Front. Endocrinol. 2018, 9, 2. [CrossRef]

59. Sommese, L.; Benincasa, G.; Schiano, C.; Marfella, R.; Grimaldi, V.; Sorriento, A.; Lucchese, R.; Fiorito, C.; Sardu, C.; Nicoletti, G.F.; et al. Genetic and epigenetic-sensitive regulatory network in immune response: A putative link between HLA-G and diabetes. Expert Rev. Endocrinol. Metab. 2019, 14, 233-241. [CrossRef] [PubMed]

60. Schwenk, R.W.; Vogel, H.; Schürmann, A. Genetic and epigenetic control of metabolic health. Mol. Metab. 2013, 2, 337-347. [CrossRef]

61. Othman, R.A.; Moghadasian, M.H. Beyond cholesterol-lowering effects of plant sterols: Clinical and experimental evidence of anti-inflammatory properties. Nutr. Rev. 2011, 69, 371-382. [CrossRef] [PubMed]

62. Berger, A.; Jones, P.J.; Abumweis, S.S. Plant sterols: Factors affecting their efficacy and safety as functional food ingredients. Lipids Health Dis. 2004, 3, 5. [CrossRef] [PubMed]

63. Abumweis, S.S.; Barake, R.; Jones, P.J. Plant sterols/stanols as cholesterol lowering agents: A meta-analysis of randomized controlled trials. Food Nutr. Res. 2008, 52. [CrossRef]

64. Demonty, I.; Ras, R.T.; Van der Knaap, H.C.; Duchateau, G.S.; Meijer, L.; Zock, P.L.; Geleijnse, J.M.; Trautwein, E.A. Continuous dose-response relationship of the LDL-cholesterol-lowering effect of phytosterol intake. J. Nutr. 2009, 139, 271-284. [CrossRef]

65. Musa-Veloso, K.; Paulionis, L.; Poon, T.; Lee, H.Y. The effects of almond consumption on fasting blood lipid levels: A systematic review and meta-analysis of randomised controlled trials. J. Nutr. Sci. 2016, 5, e34. [CrossRef]

66. Genser, B.; Silbernagel, G.; De Backer, G.; Bruckert, E.; Carmena, R.; Chapman, M.J.; Deanfield, J.; Descamps, O.S.; Rietzschel, E.R.; Dias, K.C.; et al. Plant sterols and cardiovascular disease: A systematic review and meta-analysis. Eur. Heart J. 2012, 33, 444-451. [CrossRef]

67. Talati, R.; Sobieraj, D.M.; Makanji, S.S.; Phung, O.J.; Coleman, C.I. The comparative efficacy of plant sterols and stanols on serum lipids: A systematic review and meta-analysis. J. Am. Diet. Assoc. 2010, 110, 719-726. [CrossRef]

68. Naumann, E.; Plat, J.; Mensink, R.P. Changes in serum concentrations of noncholesterol sterols and lipoproteins in healthy subjects do not depend on the ratio of plant sterols to stanols in the diet. J. Nutr. 2003, 133, 2741-2747. [CrossRef]

69. Kothari, S.; Dhami-Shah, H.; Shah, S.R. Antidiabetic Drugs and Statins in Nonalcoholic Fatty Liver Disease. J. Clin. Exp. Hepatol. 2019, 9, 723-730. [CrossRef] [PubMed]

70. Choudhury, H.; Pandey, M.; Hua, C.K.; Mun, C.S.; Jing, J.K.; Kong, L.; Ern, L.Y.; Ashraf, N.A.; Kit, S.W.; Yee, T.S.; et al. An update on natural compounds in the remedy of diabetes mellitus: A systematic review. J. Tradit. Complement. Med. 2017, 8, 361-376. [CrossRef] [PubMed]

71. Govindappa, M. A review on the role of plant(s) extracts and its phytochemicals for the management of diabetes. J. Diabetes Metab. 2015, 6, 1-38.

72. Modak, M.; Dixit, P.; Londhe, J.; Ghaskadbi, S.; Devasagayam, T.P. Indian herbs and herbal drugs used for the treatment of diabetes. J. Clin. Biochem. Nutr. 2007, 40, 163-173. [CrossRef]

73. Aggarwal, N. A Review of Recent Investigations on Medicinal Herbs Possessing Anti-Diabetic Properties. J. Nutr. Disord. Ther. 2011, 1, 2. [CrossRef]

74. Mentreddy, S.R. Medicinal plant species with potential anti-diabetic properties. J. Sci. Food Agric. 2007, 87, 743-750. [CrossRef] 
75. Governa, P.; Baini, G.; Borgonetti, V.; Cettolin, G.; Giachetti, D.; Magnano, A.R.; Miraldi, E.; Biagi, M. Phytotherapy in the Management of Diabetes: A Review. Molecules 2018, 23, 105. [CrossRef]

76. Gaikwad, B.S.; Krishna Mohan, G.; Sandhya Rani, M. Phytochemicals for diabetes management. Pharm. Crop. 2014, 5, 11-28. [CrossRef]

77. Dembinska-Kiec, A.; Mykkänen, O.; Kiec-Wilk, B.; Mykkänen, H. Antioxidant phytochemicals against type 2 diabetes. Br. J. Nutr 2008, 99, 109-117. [CrossRef]

78. Lee, Y.M.; Gweon, O.C.; Seo, Y.J.; Im, J.; Kang, M.J.; Kim, M.J.; Kim, J.I. Antioxidant effect of garlic and aged black garlic in animal model of type 2 diabetes mellitus. Nutr. Res. Pract. 2009, 3, 156-161. [CrossRef] [PubMed]

79. Tiwari, A.K.; Rao, J.M. Diabetes mellitus and multiple therapeutic approaches of phytochemicals: Present status and future prospects. Curr. Sci. 2002, 83, 30-38.

80. Zhang, X.; Yang, S.; Chen, J.; Su, Z. Unraveling the Regulation of Hepatic Gluconeogenesis. Front. Endocrinol. 2019,9 , 802. [CrossRef]

81. Misawa, E.; Tanaka, M.; Nomaguchi, K.; Yamada, M.; Toida, T.; Takase, M.; Iwatsuki, K.; Kawada, T. Administration of phytosterols isolated from Aloe vera gel reduce visceral fat mass and improve hyperglycemia in Zucker diabetic fatty (ZDF) rats. Obes. Res. Clin. Pract. 2008, 2, 239-245. [CrossRef]

82. Patil, S.B.; Takalikar, S.S.; Joglekar, M.M.; Haldavnekar, V.S.; Arvindekar, A.U. Insulinotropic and $\beta$-cell protective action of cuminaldehyde, cuminol and an inhibitor isolated from Cuminumcyminum in streptozotocin-induced diabetic rats. Br. J. Nutr. 2013, 110, 1434-1443. [CrossRef]

83. Meddah, B.; Ducroc, R.; El Abbes Faouzi, M.; Eto, B.; Mahraoui, L.; Benhaddou-Andaloussi, A.; Martineau, L.C.; Cherrah, Y.; Haddad, P.S. Nigella sativa inhibits intestinal glucose absorption and improves glucose tolerance in rats. J. Ethnopharmacol. 2009, 121, 419-424. [CrossRef]

84. Jayaprasad, B.; Sharavanan, P.S.; Sivaraj, R. Antidiabetic effect of Chloroxylonswietenia bark extracts on streptozotocin-induced diabetic rats. Beni-Suef Univ. J. Basic Appl. Sci. 2016, 5, 61-69.

85. Zhang, Y.; Feng, F.; Chen, T.; Li, Z.; Shen, Q.W. Antidiabetic and antihyperlipidemic activities of Forsythia suspensa (Thunb.) Vahl (fruit) in streptozotocin-induced diabetes mice. J. Ethnopharmacol. 2016, 192, 256-263. [CrossRef] [PubMed]

86. Mohammed, S.I.; Chopda, M.Z.; Patil, R.H.; Vishwakarma, K.S.; Maheshwari, V.L. In vivo anti-diabetic and anti-oxidant activities of Coccinia grandis leaf extract against streptozotocin-induced diabetes in experimental rats. Asian Pac. J. Trop. Dis. 2016, 6, 298-304. [CrossRef]

87. Ahangarpour, A.; Mohammadian, M.; Dianat, M. Antidiabetic effect of hydro-alcholic urtica dioica leaf extract in male rats with fructose-induced insulin resistance. Iran J. Med. Sci. 2012, 37, 181-186.

88. Jaiswal, Y.S.; Tatke, P.A.; Gabhe, S.Y.; Vaidya, A.B. Antidiabetic activity of extracts of Anacardium occidentale Linn. leaves on n-streptozotocin diabetic rats. J. Tradit. Complement. Med. 2016, 7, 421-427. [CrossRef]

89. Liu, C.T.; Hsu, T.W.; Chen, K.M.; Tan, Y.P.; Lii, C.K.; Sheen, L.Y. The Antidiabetic Effect of Garlic Oil is Associated with Ameliorated Oxidative Stress but Not Ameliorated Level of Pro-inflammatory Cytokines in Skeletal Muscle of Streptozotocin-induced Diabetic Rats. J. Tradit. Complement. Med. 2012, 2, 135-144. [CrossRef]

90. Antu, K.A.; Riya, M.P.; Nair, A.; Mishra, A.; Srivastava, A.K.; Raghu, K.G. Symplocos cochinchinensis enhances insulin sensitivity via the down regulation of lipogenesis and insulin resistance in high energy diet rat model. J. Ethnopharmacol. 2016, 193, 500-509. [CrossRef] [PubMed]

91. Hu, X.; Cheng, D.; Zhang, Z. Antidiabetic activity of Helicteresangustifolia root. Pharm. Biol. 2016, 54, 938-944. [CrossRef] [PubMed]

92. Huang, H.Y.; Korivi, M.; Yang, H.T.; Huang, C.C.; Chaing, Y.Y.; Tsai, Y.C. Effect of Pleurotus tuber-regium polysaccharides supplementation on the progression of diabetes complications in obese-diabetic rats. Chin. J. Physiol. 2014, 57, 198-208. [CrossRef]

93. Oyedemi, S.O.; Adewusi, E.A.; Aiyegoro, O.A.; Akinpelu, D.A. Antidiabetic and haematological effect of aqueous extract of stem bark of Afzelia africana (Smith) on streptozotocin-induced diabetic Wistar rats. Asian Pac. J. Trop. Biomed. 2011, 1, 353-358.

94. Emordi, J.E.; Agbaje, E.O.; Oreagba, I.A.; Iribhogbe, O.I. Antidiabetic and hypolipidemic activities of hydroethanolic root extract of Uvariachamae in streptozotocin induced diabetic albino rats. BMC Complement. Altern. Med. 2016, 16, 468. [CrossRef]

95. Palsamy, P.; Subramanian, S. Resveratrol, a natural phytoalexin, normalizes hyperglycemia in streptozotocin-nicotinamide induced experimental diabetic rats. Biomed. Pharmacother. 2008, 62, 598-605. [CrossRef]

96. El-Beshbishy, H.; Bahashwan, S. Hypoglycemic effect of basil (Ocimum basilicum) aqueous extract is mediated through inhibition of $\alpha$-glucosidase and $\alpha$-amylase activities: An in vitro study. Toxicol. Ind. Health 2012, 28, 42-50. [CrossRef] [PubMed]

97. Abubakar, A.R.; Haque, M. Preparation of Medicinal Plants: Basic Extraction and Fractionation Procedures for Experimental Purposes. J. Pharm. Bioallied Sci. 2020, 12, 1-10. [CrossRef] [PubMed]

98. Oboh, G.; Ademiluyi, A.O.; Akinyemi, A.J.; Henle, T.; Saliu, J.A.; Schwarzenbolz, U. Inhibitory effect of polyphenol-rich extracts of jute leaf (Corchorus olitorius) on key enzyme linked to type 2 diabetes ( $\alpha$-amylase and $\alpha$-glucosidase) and hypertension (angiotensin I converting) in vitro. J. Funct. Foods 2012, 4, 450-458. [CrossRef]

99. Ademiluyi, A.O.; Oboh, G.; Aragbaiye, F.P.; Oyeleye, S.I.; Ogunsuyi, O.B. Antioxidant properties and in vitro $\alpha$-amylase and $\alpha$-glucosidase inhibitory properties of phenolics constituents from different varieties of Corchorus spp. J. Taibah Univ. Med. Sci. 2015, 10, 278-287. [CrossRef] 
100. Ademiluyi, A.O.; Oboh, G. Soybean phenolic-rich extracts inhibit key-enzymes linked to type 2 diabetes ( $\alpha$-amylase and $\alpha$ glucosidase) and hypertension (angiotensin I converting enzyme) in vitro. Exp. Toxicol. Pathol. 2013, 65, 305-309. [CrossRef] [PubMed]

101. Choo, C.Y.; Sulong, N.Y.; Man, F.; Wong, T.W. Vitexin and isovitexin from the leaves of Ficusdeltoidea with in-vivo $\alpha$-glucosidase inhibition. J. Ethnopharmacol. 2012, 142, 776-781. [CrossRef] 